\title{
Transportation Planning for Irradiated Fuel- Cladding and Integral FeCrAl Experiments
}

Nuclear Technology

Research and Development

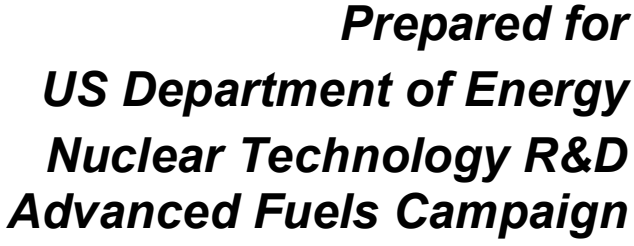

Annabelle G. Le Coq, Rodger C. Martin, and Kory D. Linton Oak Ridge National Laboratory 



\section{DISCLAIMER}

This information was prepared as an account of work sponsored by an agency of the U.S. Government. Neither the U.S. Government nor any agency thereof, nor any of their employees, makes any warranty,

expressed or implied, or assumes any legal liability or responsibility for the accuracy, completeness, or usefulness, of any information, apparatus, product, or process disclosed, or represents that its use would not infringe privately owned rights. References herein to any specific commercial product, process, or service by trade name, trade mark, manufacturer, or otherwise, does not necessarily constitute or imply its endorsement, recommendation, or favoring by the U.S. Government or any agency thereof. The views and opinions of authors expressed herein do not necessarily state or reflect those of the U.S. Government or any agency thereof. 


\section{ACKNOWLEDGMENTS}

This research was sponsored by the Advanced Fuels Campaign (AFC) of the US Department of Energy (DOE) Office of Nuclear Energy. The report was authored by UT-Battelle under Contract No. DE-AC0500OR22725 with the US Department of Energy. 


\section{SUMMARY}

Building the material database for accident tolerant fuel concepts requires movement of experiments to ORNL from other national laboratories, commercial reactors, and international collaborators. This report summarizes the current fleet of available and proposed casks for handling small scale fuel shipments and the immediate challenges to be addressed in order to perform shipments in support of accident tolerant fuels development under the Advanced Fuels Campaign. Shipping recommendations and a description of unresolved issues associated with the shipment are provided for three experiments: ATF-1 LOCA (ATF-18), the Halden irradiated Instrumented Fuel Assembly (IFA) 796 experiment, and the Hatch lead test rods. Each of these experiments represents an important step in continuing the accelerated testing of $\mathrm{FeCrAl}$ cladding for commercial applications. 


\section{CONTENTS}

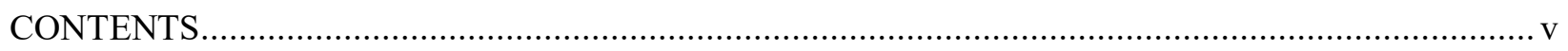

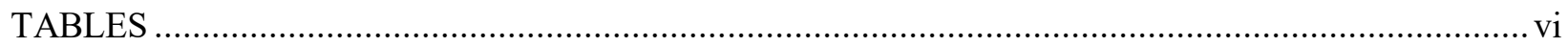

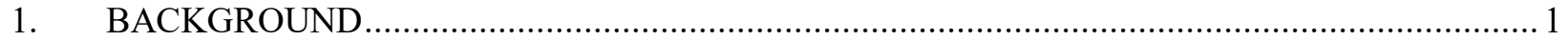

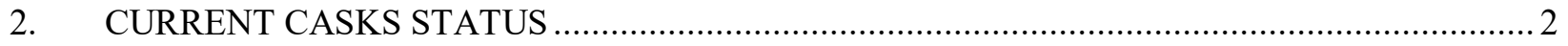

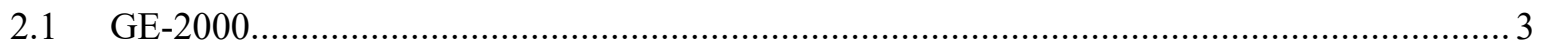

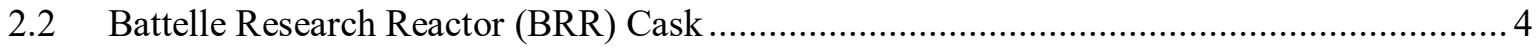

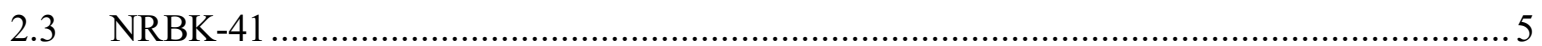

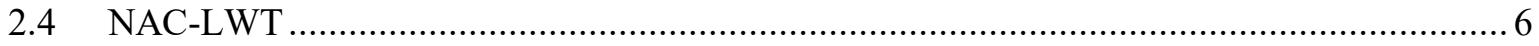

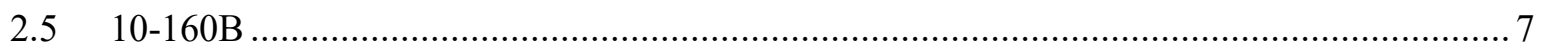

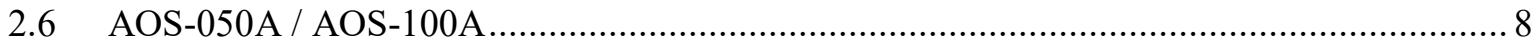

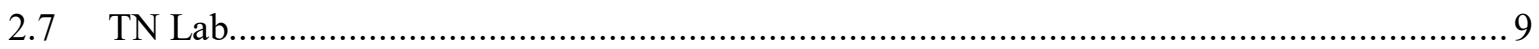

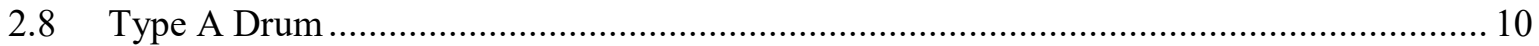

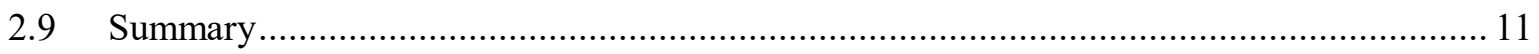

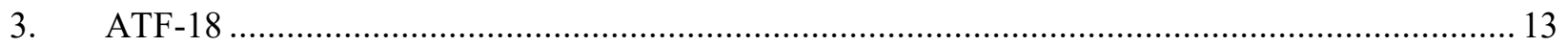

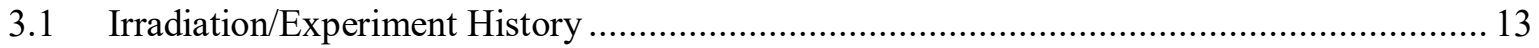

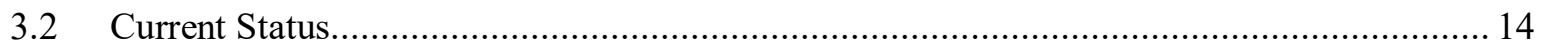

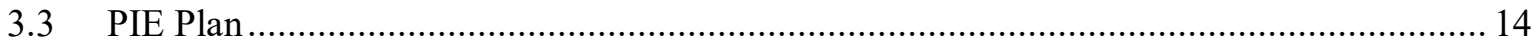

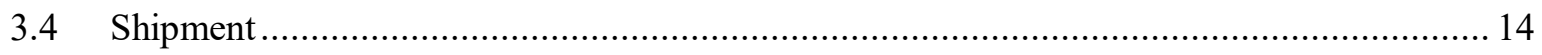

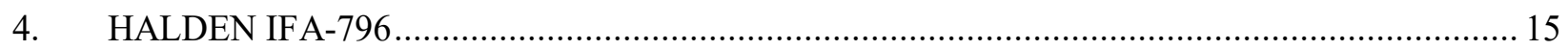

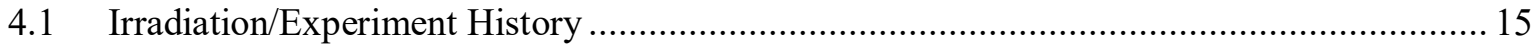

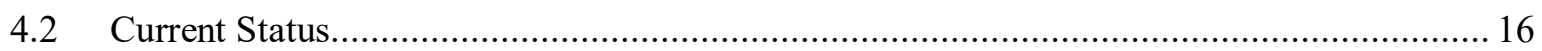

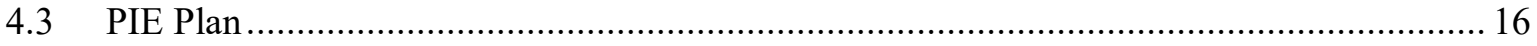

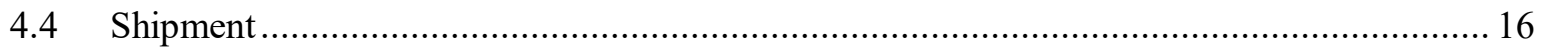

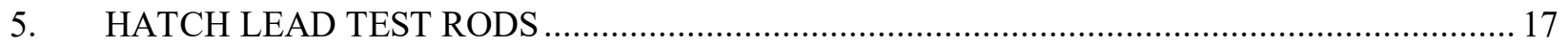

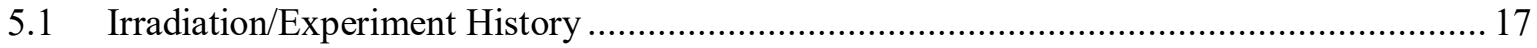

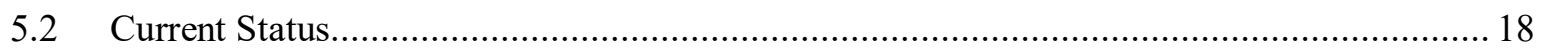

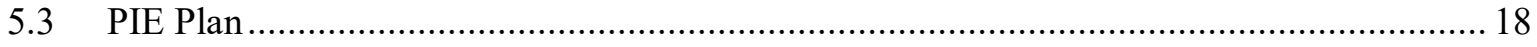

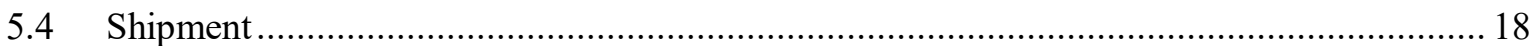

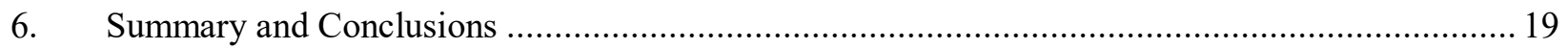

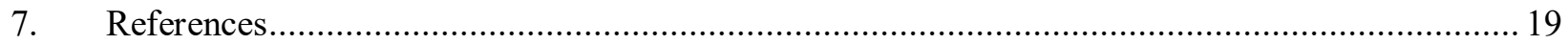




\section{FIGURES}

Figure 1. R\&D program design strategy. Filled polygons represent a qualitative assessment on the extent of testing completed regarding the specified topic. 1

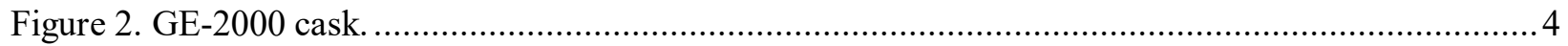

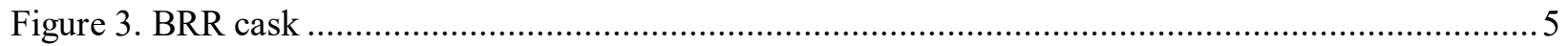

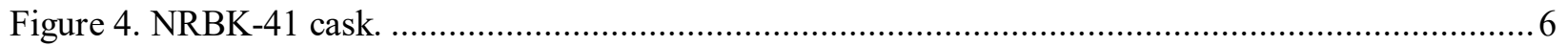

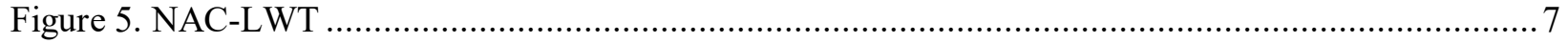

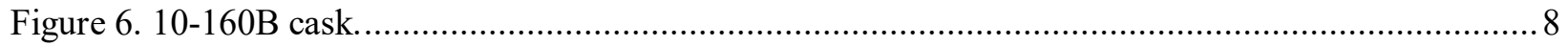

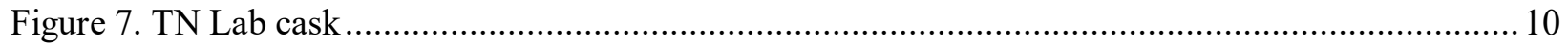

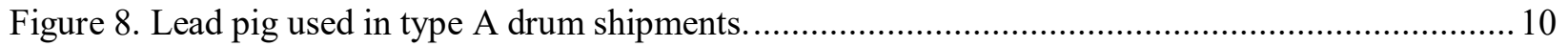

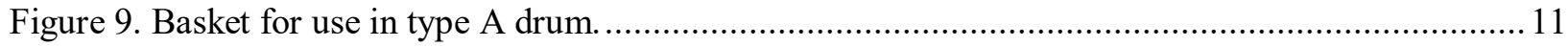

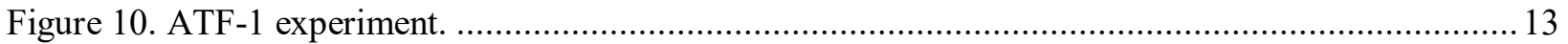

Figure 11. Visual examination and neutron radiography of the ORNL LOCA FCA-L3 rodlet with a neutron radiography detail showing cracking in the $\mathrm{UO}_{2}$ pellets....................................... 14

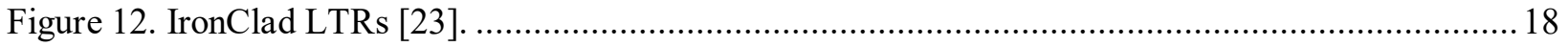

\section{TABLES}

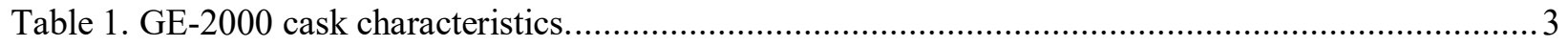

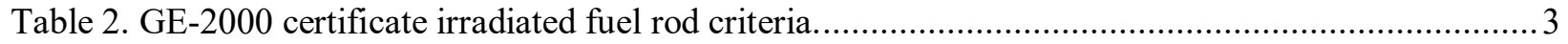

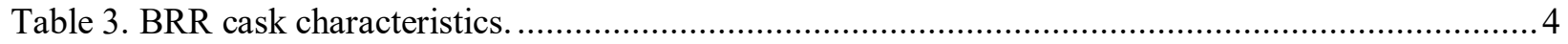

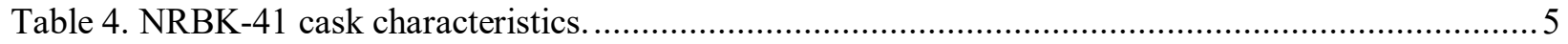

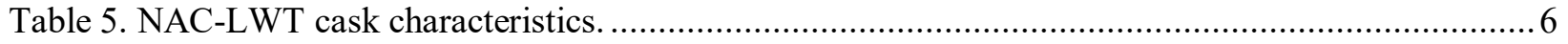

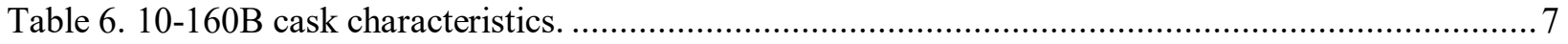

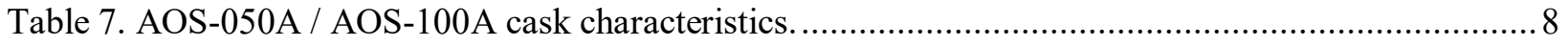

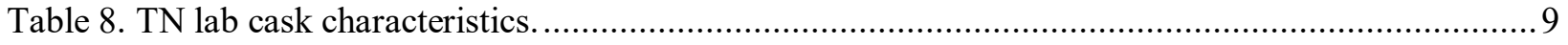

Table 9. Summary of the characteristics of the different type B packages ............................................ 12

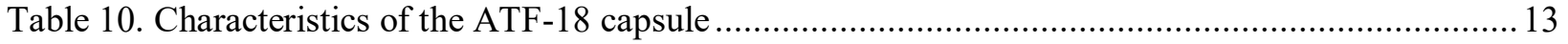

Table 11. ATF-18 radionuclides inventory after 2 years of cooling ............................................... 15

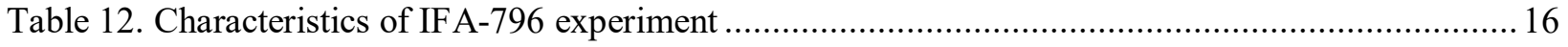

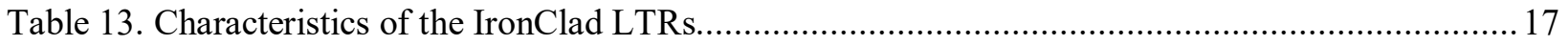




\section{ACRONYMS}

$\begin{array}{ll}\text { ARMOR } & \text { Abrasion Resistant, More Oxidation Resistant } \\ \text { AFC } & \text { Advanced Fuels Campaign } \\ \text { ATF } & \text { accident-tolerant fuel } \\ \text { ATR } & \text { Advanced Test Reactor } \\ \text { BRR } & \text { Battelle Research Reactor } \\ \text { BWR } & \text { boiling water reactor } \\ \text { CAC } & \text { Competent Authority Certification } \\ \text { CoC } & \text { certificate of compliance } \\ \text { DOE-NE } & \text { US Department of Energy Office of Nuclear Energy } \\ \text { DOT } & \text { US Department of Transportation } \\ \text { FCCI } & \text { fuel-cladding chemical interaction } \\ \text { FY } & \text { fiscal year } \\ \text { GASR } & \text { gas assay, sample, and recharge } \\ \text { GE } & \text { General Electric } \\ \text { GNF } & \text { Global Nuclear Fuels } \\ \text { HFEF } & \text { Hot Fuel Examination Facility } \\ \text { HFIR } & \text { High Flux Isotope Reactor } \\ \text { IAEA } & \text { International Atomic Energy Agency } \\ \text { IFA } & \text { instrumented fuel assembly } \\ \text { IFEL } & \text { Irradiated Fuels Examination Laboratory } \\ \text { INL } & \text { Idaho National Laboratory } \\ \text { LOCA } & \text { loss-of-coolant accident } \\ \text { LTA } & \text { lead test assembly } \\ \text { LTR } & \text { lead test rod } \\ \text { LWR } & \text { light water reactor } \\ \text { NRC } & \text { US Nuclear Regulatory Commission } \\ \text { NSUF } & \text { Nuclear Science User Facility } \\ \text { ORNL } & \text { Oak Ridge National Laboratory } \\ \text { PIE } & \text { post-irradiation examination } \\ \text { PWR } & \text { pressurized water reactor } \\ \text { RIA } & \text { reactivity insertion accident } \\ \text { SAR } & \text { safety analysis report } \\ \text { SATS } & \text { severe accident test station } \\ & \\ & \end{array}$




\section{TRANSPORTATION PLANNING FOR IRRADIATED FUEL- CLADDING AND INTEGRAL FeCrAI EXPERIMENTS}

\section{BACKGROUND}

Following the Fukushima Daiichi nuclear power plant accident in 2011, the US Department of Energy Office of Nuclear Energy (DOE-NE) initiated the development of accident-tolerant fuel (ATF) concepts aimed at commercial deployment of nuclear fuels and materials with enhanced accident tolerance. In the years following, the DOE-NE Advanced Fuels Campaign (AFC) has leveraged infrastructure and expertise within the national laboratories, universities, and industry to develop and evaluate new cladding concepts including iron-chromium-aluminum alloys, referred to as $\mathrm{FeCrAl}$.

FeCrAl alloys have shown enhanced resistance to oxidation, corrosion, stress corrosion cracking, and irradiation-induced swelling based on in-pile and out-of-pile experiments on Generation I and II alloy variants [1]. The robust R\&D program depicted in Figure 1 has largely moved out of the foundational and iterative alloy development phase and into the more complex integral tests, including fueled irradiations in test reactors, which can stretch over many years.

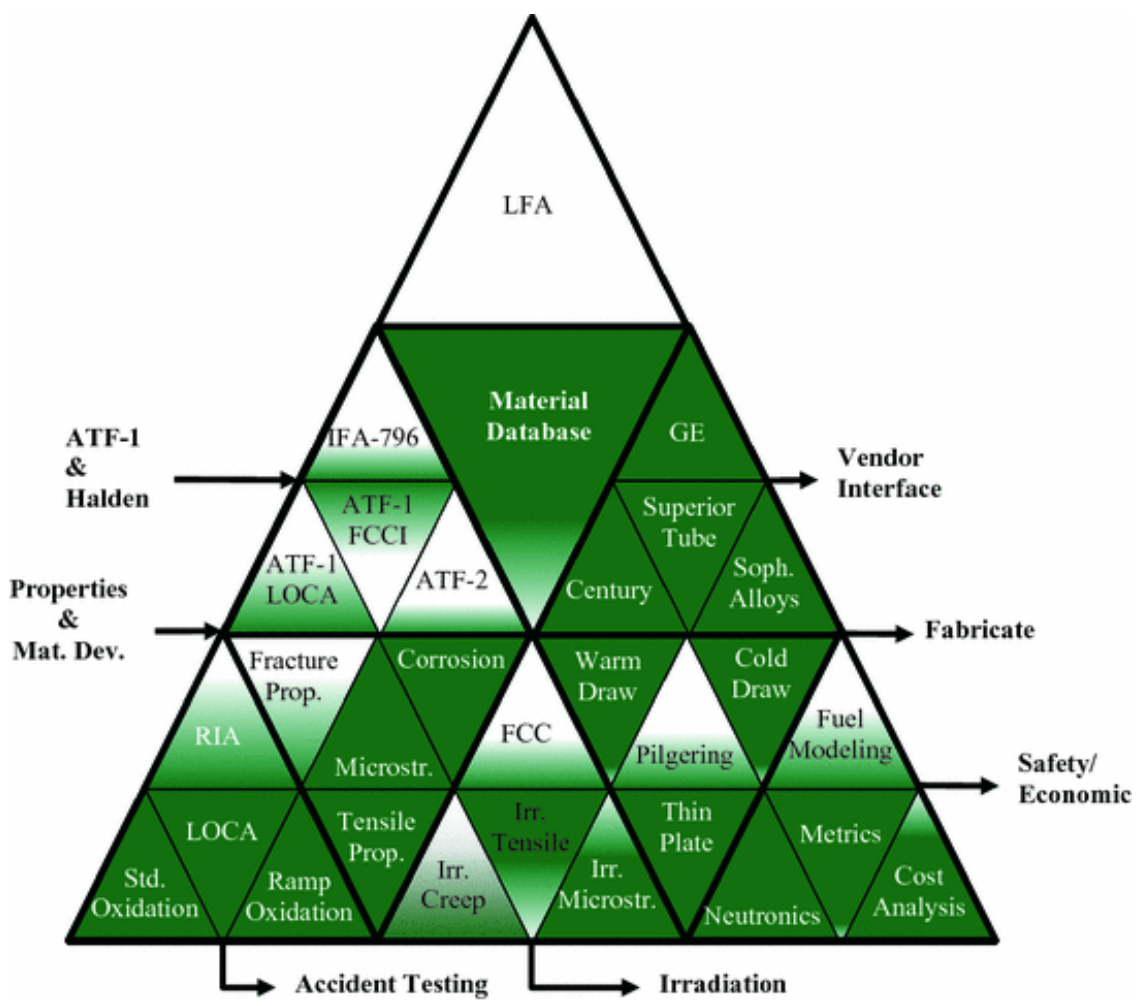

Figure 1. R\&D program design strategy.

Filled polygons represent a qualitative assessment on the extent of testing completed regarding the specified topic.

Std. $=$ standard

LOCA = loss-of-coolant accident

RIA = reactivity insertion accident

Irr. = irradiation

Microstr. $=$ microstructure
FCCI $=$ fuel-cladding chemical interaction

Soph. $=$ Sophisticated

LTR $=$ lead test rod

GE $=$ General Electric Corporation [1] 
The diagram above includes two integral tests-ATF-1 LOCA and IFA-796-which have completed the irradiation phase and require a fissile material cask shipment to Oak Ridge National Laboratory (ORNL) to continue populating the FeCrAl material property database. Additional integral tests for FeCrAl development include the ATF-2 loop irradiation and the lead test rod/lead test assembly (LTR/LTA) commercial reactor irradiations. While the post-irradiation examination (PIE) for the later experiments will be years in the making, planning the shipment of the ATF-1 LOCA experiment and IFA-796 Halden experiment have highlighted the lack of options available to move small-scale fueled experiments to national laboratories, whether the shipments originate at commercial reactors in the US, in experimental reactors overseas, or even in other US national laboratories.

This report summarizes the current and upcoming fleet of casks used or proposed for use at ORNL and describes some of the issues regarding the current fleet, including lack of availability, lack of appropriate approval documents, infrastructure limitations, and size limitations. The report also explores the shipment options on three near-term, impactful experiments: ATF-1 LOCA (ATF-18), the Halden irradiated Instrumented Fuel Assembly (IFA)-796 experiment, and the Hatch lead test rods. Each of these experiments represents an important step in continuing the accelerated testing of FeCrAl cladding for commercial applications.

\section{CURRENT CASKS STATUS}

This section presents different casks that have been used or are intended for use in national laboratories and could be used for future shipments to ORNL. The information presented corresponds to the current bounding case's approved certificate. The listed casks with certificates expiring in the next 11/2 years will be subject to revision of their certificates. Casks are either known to be completely unavailable or generally available; further investigation should be performed to determine the lead times and scheduling of rentals for available casks.

Different types of certificates can be issued [2] depending on the content to be transported and the countries involved in the cask shipment:

- A US Nuclear Regulatory Commission (NRC) certificate of compliance (CoC) is issued in accordance with 10 CFR Part 71 [3] and is used for transportation within the United States.

- A DOE CoC is issued in accordance with 49 CFR 173.7 [4] and is primarily used for shipments between DOE sites; such a certificate is affiliated with an NRC CoC and can present specific DOE contents.

- The US Department of Transportation (DOT) issues a Competent Authority Certification (CAC) for a Type B or fissile radioactive materials package for export based on endorsement of package description and authorized radioactive contents from a DOE or NRC CoC, or for import of foreign package designs.

The different types of packages and materials are defined in the International Atomic Energy Agency (IAEA) safety standards SSR-6 [5]. 


\subsection{GE-2000}

The GE-2000 cask (Figure 2) is an NRC- and DOE-approved package with the characteristics presented in Table 1 below:

Table 1. GE-2000 cask characteristics.

\begin{tabular}{l|l}
\hline Characteristic & Specification \\
\hline Certificate number & NRC : USA/9228/B(U)-96, Rev. 27 \\
& DOE: USA/9228/B(U)-96, Rev. 0 \\
\hline Expiration date & NRC: 03/31/2023 \\
& DOE: 08/31/2020 \\
\hline Designer & General Electric \\
\hline Overall diameter & $72 \mathrm{in} / 1.83 \mathrm{~m}$ \\
\hline Overall length & $131.5 \mathrm{in} / 3.34 \mathrm{~m}$ \\
\hline Cavity diameter & $26.5 \mathrm{in} / 0.67 \mathrm{~m}$ \\
\hline Cavity length & $54 \mathrm{in} / 1.37 \mathrm{~m}$ \\
\hline Maximal package mass & $33,500 \mathrm{lb} / 15,195 \mathrm{~kg}$ \\
\hline Maximal content mass & $5,450 \mathrm{lb} / 2,472 \mathrm{~kg}$ \\
\hline Transportation mode & Air transport not authorized for fissile materials \\
\hline Loading & Dry or wet, vertical \\
\hline
\end{tabular}

This cask has been used at the Hot Fuel Examination Facility (HFEF) at Idaho National Laboratory (INL). However, it has never been used at ORNL's Irradiated Fuels Examination Laboratory (IFEL). Its handling at IFEL could be an issue; the cask height is known to be on the very edge of the air lock door height. Alternatively, a horizontal loading and handling procedure would need to be established. This subject would have to be investigated to conclude on the suitability of the GE-2000 for use at IFEL. Global Nuclear Fuels (GNF) and ORNL each own one GE-2000 cask. The ORNL GE-2000 is owned by DOE's Office of Science for the transfer of High Flux Isotope Reactor (HFIR) fuel elements to Savanah River National Laboratory and is not available for use.

The GE-2000 certificate covers the following contents:

- $\quad$ irradiated fuel rods, which may be cut or segmented, meeting the criteria specified in one of the three columns in Table 2 below (DOE CoC):

Table 2. GE-2000 certificate irradiated fuel rod criteria.

\begin{tabular}{|c|c|c|c|c|}
\hline Criterion & Unit & $\mathbf{A}$ & $\mathbf{B}$ & $\mathbf{C}$ \\
\hline Decay heat & $\mathrm{W}$ & \multicolumn{3}{|c|}{$\leq 600$} \\
\hline Fissile content & $\mathrm{g}{ }^{235} \mathrm{U}$ equivalent mass & $\leq 1,175$ & $\leq 1,750$ & $\leq 242$ \\
\hline Initial enrichment & wt. $\%$ in the fissile isotope & \multicolumn{3}{|c|}{$\leq 5 \%$} \\
\hline Pellet diameter & in $/ \mathrm{mm}$ & $\geq 0.3 / 7.62$ & $\geq 0.35 / 8.89$ & $\geq 0.3 / 7.62$ \\
\hline Burnup & GWd/MTU & $\leq 45$ & $\leq 38$ & $\leq 52$ \\
\hline Cooling time & days & $\geq 120$ & $\geq 120$ & $\geq 180$ \\
\hline
\end{tabular}

- irradiated hardware components composed of stainless steels, carbon steels, nickel and zirconium alloys, irradiated byproducts such as control rods and/or control blades containing either hafnium or boron carbide (NRC $\mathrm{CoC}$ ). The cooling time should be at least 30 days. Fissile material not exceeding the exempt quantity can be transported. 
A revision of the safety analysis report (SAR) is planned for the summer of 2019 to support a revision of the current DOE CoC. In addition, the licensing efforts are focusing on adding irradiated fuel rod content to the NRC CoC; the submission of the amended SAR is planned for 2019 for requested NRC approval in $2020[6]$.

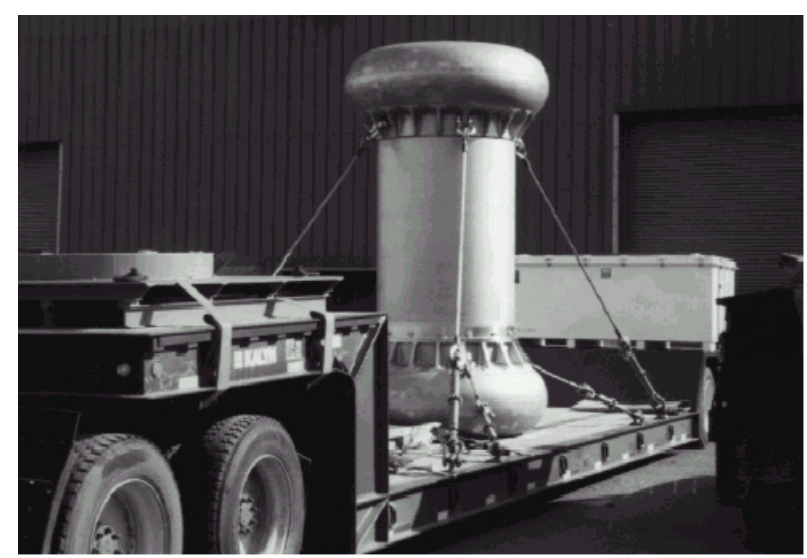

Figure 2. GE-2000 cask.

\subsection{Battelle Research Reactor (BRR) Cask}

The BRR cask (Figure 3) is an NRC-approved package, with the characteristics shown below in Table 3:

Table 3. BRR cask characteristics.

\begin{tabular}{l|l}
\hline Characteristic & Specification \\
\hline Certificate number & USA/9341/B(U)F-96 Rev. 6 \\
\hline Expiration date & $01 / 31 / 2020$ \\
\hline Designer & ORANO \\
\hline Overall diameter & 78 in $/ 1.98 \mathrm{~m}$ \\
\hline Overall length & $119.5 \mathrm{in} / 3.04 \mathrm{~m}$ \\
\hline Cavity diameter & $16 \mathrm{in} / 0.41 \mathrm{~m}$ \\
\hline Cavity length & 54 in $/ 1.37 \mathrm{~m}$ \\
\hline Maximal package mass & $32,000 \mathrm{lb} / 14,515 \mathrm{~kg}$ \\
\hline Maximal content mass & - \\
\hline Transportation mode & Road or rail \\
\hline Loading & Wet or dry, vertical \\
\hline
\end{tabular}

INL owns a BRR cask that was previously used at HFEF. Two additional BRR casks are planned to be fabricated by the summer of 2019. The current CoC allows the transportation of fuel elements or loose fuel plates from different research reactors. A current one-time use amendment allows for refabricated experimental fueled rodlets to be transported from ORNL to INL. Another amendment is required to cover the existing needs of the Nuclear Science User Facility (NSUF), the AFC, and other DOE-NE programs. This effort is being led by Collin Knight (INL), but no amendment has been submitted to date. 


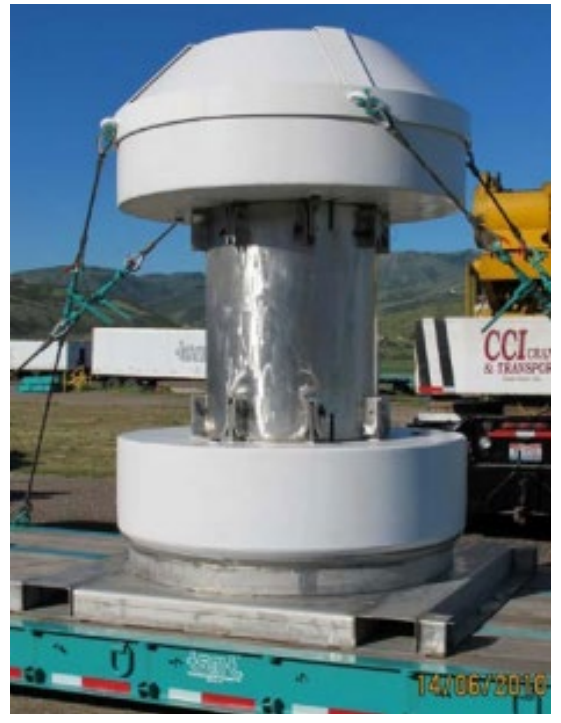

Figure 3. BRR cask

\subsection{NRBK-41}

Th NRBK-41 cask (Figure 4) is NRC-approved and has the characteristics shown in Table 4 below:

Table 4. NRBK-41 cask characteristics.

\begin{tabular}{l|l}
\hline Characteristic & Specification \\
\hline Certificate number & USA $/ 9221 / \mathrm{B}(\mathrm{M}) \mathrm{F}-96 \mathrm{Rev} .6$ \\
\hline Expiration date & $04 / 30 / 2023$ \\
\hline Designer & $\mathrm{DOE}$ \\
\hline Overall diameter & $27.2 \mathrm{in} / 0.69 \mathrm{~m}$ \\
\hline Overall length & $40 \mathrm{in} / 1.03 \mathrm{~m}$ \\
\hline Cavity diameter & $5 \mathrm{in} / 0.13 \mathrm{~m}$ \\
\hline Cavity length & $16 \mathrm{in} / 0.41 \mathrm{~m}$ \\
\hline Maximal package mass & $9,000 \mathrm{lb} / 4,082 \mathrm{~kg}$ \\
\hline Maximal content mass & $60 \mathrm{lb} / 27 \mathrm{~kg}$ \\
\hline Transportation mode & Air transport of fissile material not authorized \\
\hline Loading & Vertical \\
\hline
\end{tabular}

The content allowed for transportation in this cask is byproduct and special nuclear material in solid form with a fissile content limited to 350 equivalent grams of ${ }^{235} \mathrm{U}$ and a decay heat load of $240 \mathrm{Btu} / \mathrm{hr}(70.3 \mathrm{~W})$ maximum. This cask has previously been used at HFEF and IFEL. DOE Naval Reactors owns about 5 casks of this type, but they are not clearly available for use outside the Naval Reactor programs. 


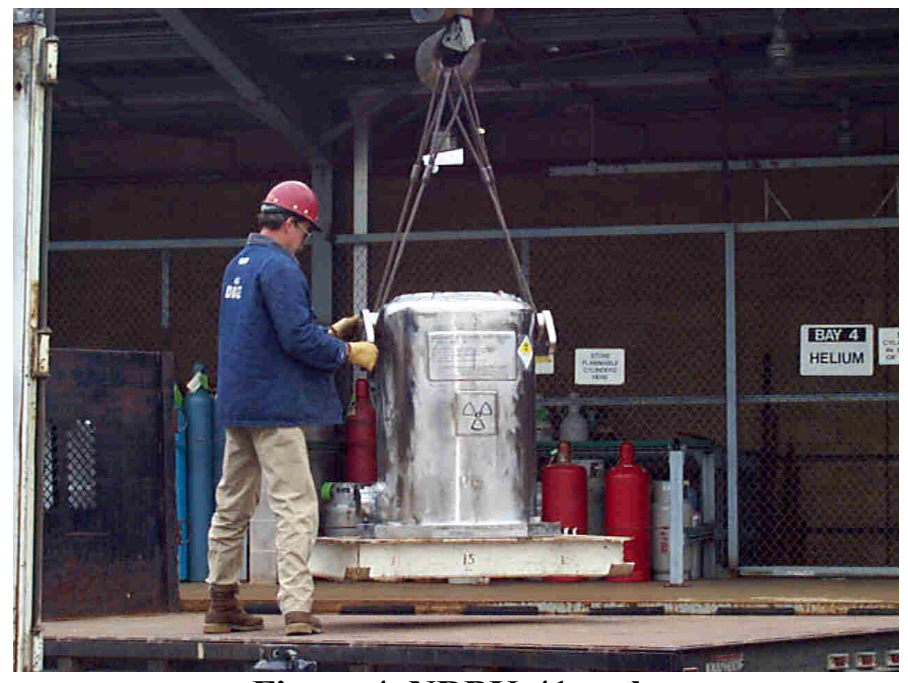

Figure 4. NRBK-41 cask.

\section{$2.4 \quad$ NAC-LWT}

This NRC-, DOT- and DOE-approved cask (Figure 5) has the characteristics presented in Table 5:

Table 5. NAC-LWT cask characteristics.

\begin{tabular}{l|l}
\hline Characteristic & Specification \\
\hline Certificate number & NRC: USA/9225/B(U)F-96 Rev. 68 \\
& DOT: USA/9225/B(U)F-96 Rev. 61 \\
& DOE: USA/9225/B(U)F-96 Rev. 12 \\
\hline Expiration date & DOT/NRC: 04/30/2020 \\
& DOE: 09/30/2022 \\
\hline Designer & NAC International Inc. \\
\hline Overall diameter & 65.3 in $/ 1.66 \mathrm{~m}$ \\
\hline Overall length & $232 \mathrm{in} / 5.89 \mathrm{~m}$ \\
\hline Cavity diameter & $13.4 \mathrm{in} / 0.34 \mathrm{~m}$ \\
\hline Cavity length & 178 in $/ 4.52 \mathrm{~m}$ \\
\hline Maximal package mass & $52,000 \mathrm{lb} / 23,587 \mathrm{~kg}$ \\
\hline Maximal content mass & $4,000 \mathrm{lb} / 1,814 \mathrm{~kg}$ \\
\hline Transportation mode & Air transport not authorized \\
\hline Loading & Dry and wet, vertical and horizontal \\
\hline
\end{tabular}

This cask is used to transport contents including unirradiated or irradiated pressurized water reactor (PWR) and boiling water reactor (BWR) fuel assemblies and rods, or metallic fuel rods containing natural uranium pellets with aluminum cladding (DOT and NRC certificates).

The NAC-LWT has been previously used at HFEF and IFEL and is likely more than sufficient for any shipments of ATF experiments. Unfortunately, the cask loans are known to be expensive, and the size is beyond the needs of most R\&D-scale activities. 


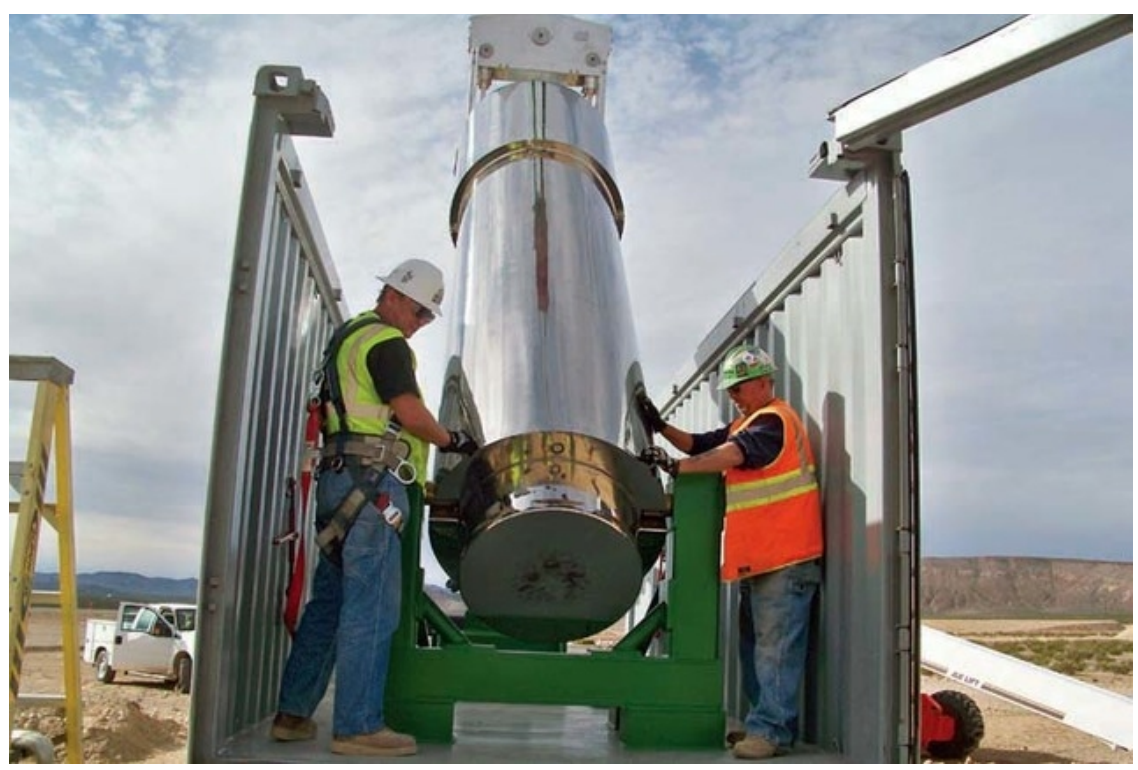

Figure 5. NAC-LWT

\section{$2.5 \quad 10-160 B$}

This DOT-, DOE- and NRC-approved cask (Figure 6) has the characteristics presented in Table 6:

Table 6. 10-160B cask characteristics.

\begin{tabular}{l|l}
\hline Characteristic & Specification \\
\hline Certificate number & DOT: USA/9204/B(U)F-96 Rev. 5 \\
& DOE: USA/9204/B(U)F-96 Rev. 10 \\
& NRC: USA/9204/B(U)F-96 Rev. 22 \\
\hline Expiration date & DOT/NRC: $10 / 31 / 2020$ \\
& DOE: $12 / 31 / 2020$ \\
\hline Designer & Energy Solutions \\
\hline Overall diameter & 102 in $/ 2.59 \mathrm{~m}$ \\
\hline Overall length & $130 \mathrm{in} / 3.30 \mathrm{~m}$ \\
\hline Cavity diameter & $68 \mathrm{in} / 1.73 \mathrm{~m}$ \\
\hline Cavity length & 77 in $/ 1.96 \mathrm{~m}$ \\
\hline Maximal package mass & $72,000 \mathrm{lb} / 32,659 \mathrm{~kg}$ \\
\hline Maximal content mass & $14,250 \mathrm{lb} / 6,464 \mathrm{~kg}$ \\
\hline Transportation mode & Air transport of fissile material not authorized \\
\hline Loading & Dry and wet \\
\hline
\end{tabular}

The contents allowed for transportation in this cask include:

- Byproduct, source, and special nuclear material, non-fissile or fissile-excepted, as special form or nonspecial form in the form of process solids or resins; either dewatered, solid, or solidified waste; in secondary containers;

- Dewatered, solid, or solidified transuranic-containing wastes; fissile, non-fissile, or fissileexcepted; in secondary containers; 
- Miscellaneous radioactive solid waste materials, including special form materials and powdered solids in secondary containers with a maximum decay heat of $200 \mathrm{~W}$.

This cask has not been used at HFEF or IFEL to date, but it has been used onsite at ORNL. The cask loans can be expensive, and the handling can be inconvenient.

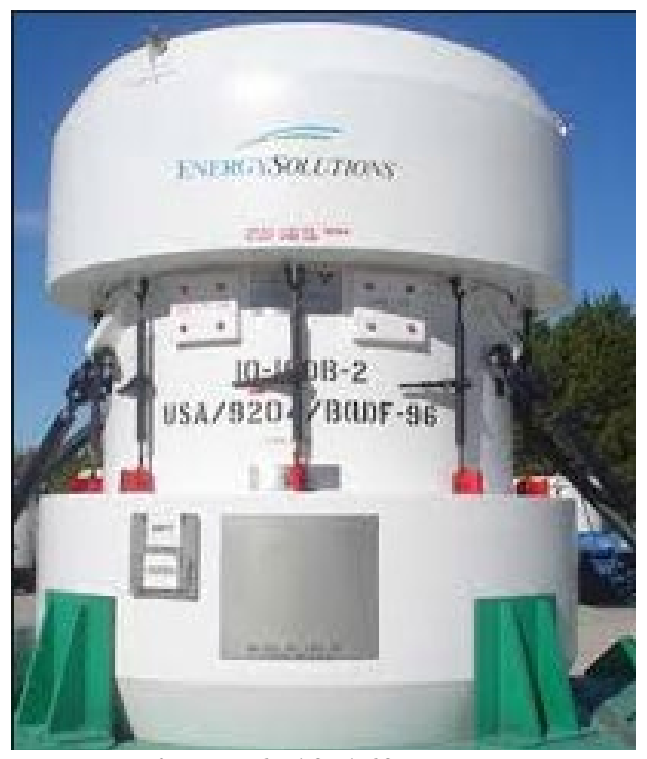

Figure 6. 10-160B cask.

\subsection{AOS-050A / AOS-100A}

Those NRC- and DOT-approved casks have the characteristics presented in Table 7 below:

Table 7. AOS-050A / AOS-100A cask characteristics.

\begin{tabular}{|c|c|c|}
\hline Characteristic & \multicolumn{2}{|c|}{ Specification } \\
\hline & AOS-050A & AOS-100A \\
\hline Certificate number & \multicolumn{2}{|c|}{$\begin{array}{l}\text { NRC: USA/9316/B(U)F-96 Rev. } 8 \\
\text { DOT: USA/9316/B(U)F-96 Rev. } 4\end{array}$} \\
\hline Expiration date & \multicolumn{2}{|c|}{$7 / 31 / 2021$} \\
\hline Designer & \multicolumn{2}{|c|}{ Alpha-Omega Services, Inc. } \\
\hline Overall diameter & $35.8 \mathrm{in} / 0.91 \mathrm{~m}$ & $61 \mathrm{in} / 1.55 \mathrm{~m}$ \\
\hline Overall length & $38.6 \mathrm{in} / 0.98 \mathrm{~m}$ & $75.4 \mathrm{in} / 1.92 \mathrm{~m}$ \\
\hline Cavity diameter & $3.25 \mathrm{in} / 0.08 \mathrm{~m}$ & $6.5 \mathrm{in} / 0.17 \mathrm{~m}$ \\
\hline Cavity length & $10 \mathrm{in} / 0.25 \mathrm{~m}$ & $20 \mathrm{in} / 0.51 \mathrm{~m}$ \\
\hline Maximal package mass & $1,500 \mathrm{lb} / 680 \mathrm{~kg}$ & $12,500 \mathrm{lb} / 5,670 \mathrm{~kg}$ \\
\hline Maximal content mass & $60 \mathrm{lb} / 27 \mathrm{~kg}$ & $500 \mathrm{lb} / 227 \mathrm{~kg}$ \\
\hline Transportation mode & \multicolumn{2}{|l|}{ All } \\
\hline Loading & \multicolumn{2}{|l|}{ Dry and wet } \\
\hline
\end{tabular}

These casks are intended for transportation of activation product radioactive materials as normal or special form [7]. The maximum decay heat is $100 \mathrm{~W}$ for the AOS-050A and $400 \mathrm{~W}$ for the AOS-100A, and the 
maximum weight is $60 \mathrm{lb}(27 \mathrm{~kg})$ for the AOS-050A and $500 \mathrm{lb}(227 \mathrm{~kg})$ for the AOS-100A. Fissile materials and irradiated fissile materials containing fission products are prohibited.

The rental cost of the AOS-050A cask is around $\$ 20,000 /$ week, and it is approximately $\$ 35,000 /$ week for the AOS-100A.

\subsection{TN Lab}

The TN Lab cask (Figure 7), previously called the Flying Pig, has the characteristics shown in Table 8 below:

Table 8. TN lab cask characteristics.

\begin{tabular}{l|l}
\hline Certificate number & $\begin{array}{l}\text { B(U) French certificate expected by March 2019 } \\
\text { Validation in the US to initiate }\end{array}$ \\
\hline Expiration date & - \\
\hline Designer & ORANO \\
\hline Overall diameter & $43.3 \mathrm{in} / 1.10 \mathrm{~m}$ \\
\hline Overall length & $70.9 \mathrm{in} / 1.80 \mathrm{~m}$ \\
\hline Cavity diameter & $5.9 \mathrm{in} / 0.150 \mathrm{~m}$ \\
\hline Cavity length & $14.2 \mathrm{in} / 0.360 \mathrm{~m}$ \\
\hline Maximal package mass & $6,173 \mathrm{lb} / 2,800 \mathrm{~kg}$ \\
\hline Maximal content mass & - \\
\hline Transportation mode & All modes authorized \\
\hline Loading & Dry only*, vertical and horizontal \\
\hline * The upcoming certificate will only alloy dry loading. However, an amendment could allow wet loading.
\end{tabular}

The TN Lab cask is intended to be a cost effective, flexible solution for transport of samples or irradiated material. The fissile quantity allowed for transportation is limited to fissile excepted quantities [7]. The French $\mathrm{B}(\mathrm{U})$ certificate, when issued, will be valid in any other country covered by the European Agreement Concerning the International Carriage of Dangerous Goods by Road (ADR) [8]; an information letter to the ADR country's competent authority must be sent to inform about the use of the cask. Norway is a signatory to the ADR [8]. The timeline to obtain the US CAC is currently uncertain and a request has yet to be submitted.

A unique cask has been fabricated. The price to use this cask is 10,000 euros $(\sim \$ 11,500)$ per week. 


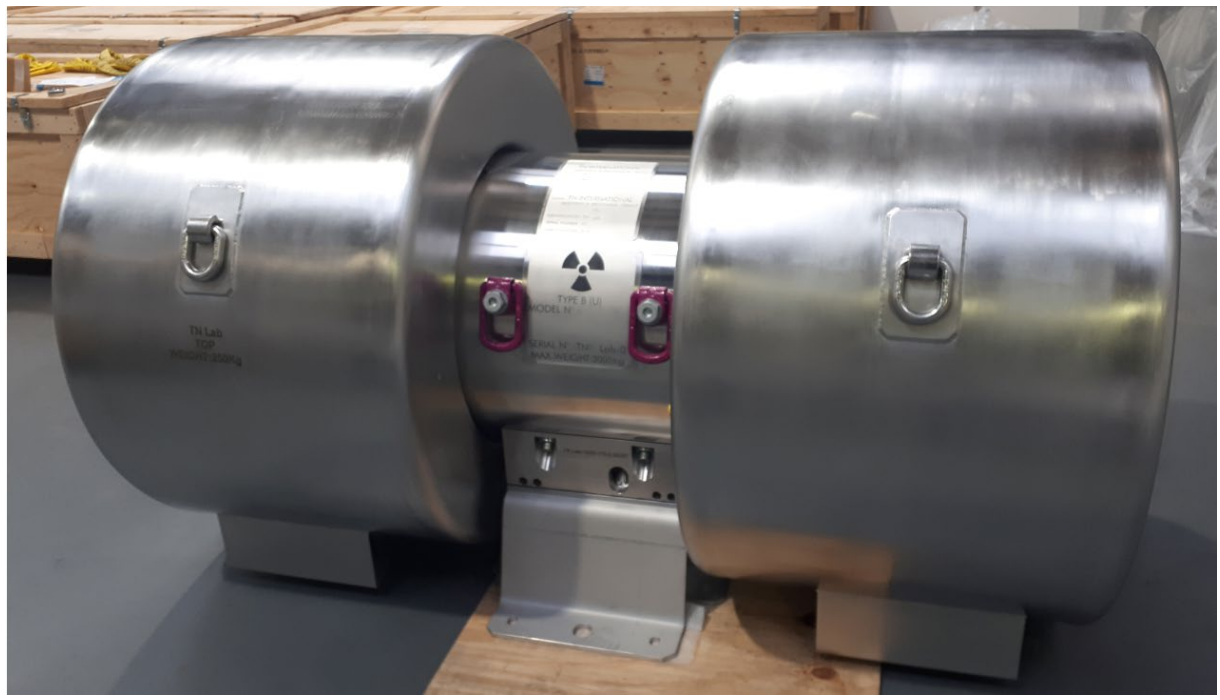

Figure 7. TN Lab cask

\section{$2.8 \quad$ Type A Drum}

ORNL uses a 5- gallon Type A drum containing a shielded lead pig (see Figure 8). The cavity has a 3-inch diameter $(76 \mathrm{~mm})$ and is 6.05 inches $(153.7 \mathrm{~mm})$ long. The material that can be shipped in this drum can be fissile; the fissile quantity must correspond to a non-fissile or fissile excepted material, as defined in the IAEA regulations [5]. As shown in Figure 9, a basket can be placed in the drum's cavity.

The Type A drum has been used domestically and internationally.

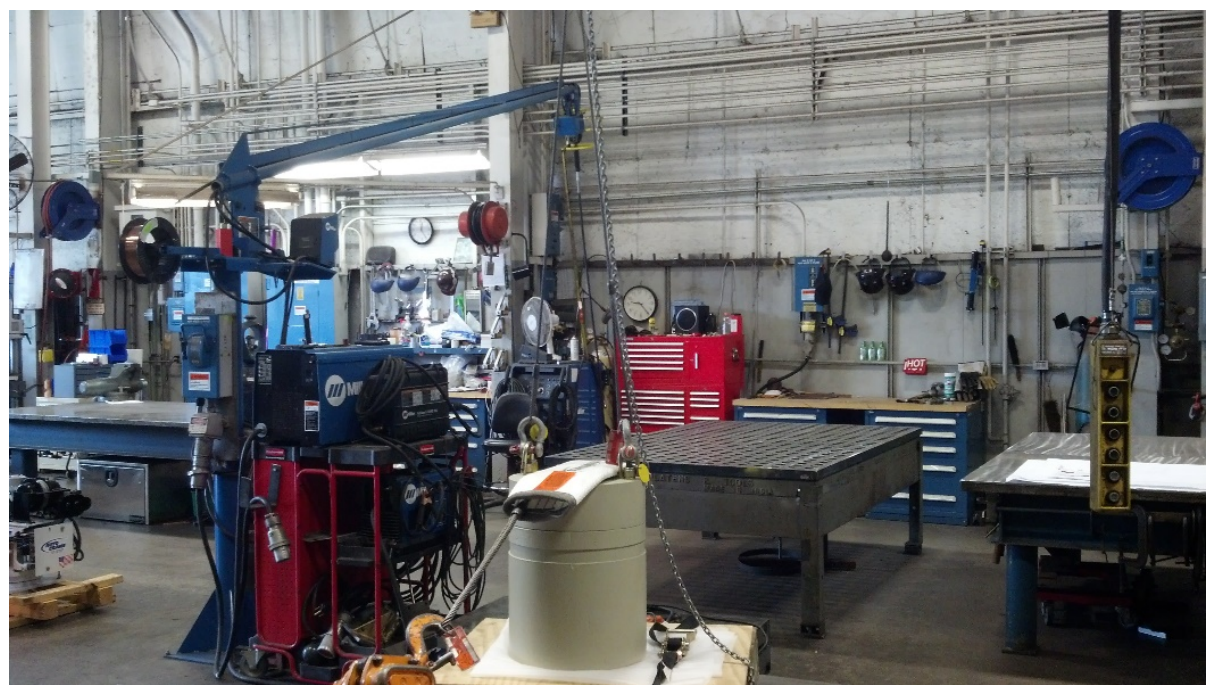

Figure 8. Lead pig used in type A drum shipments. 


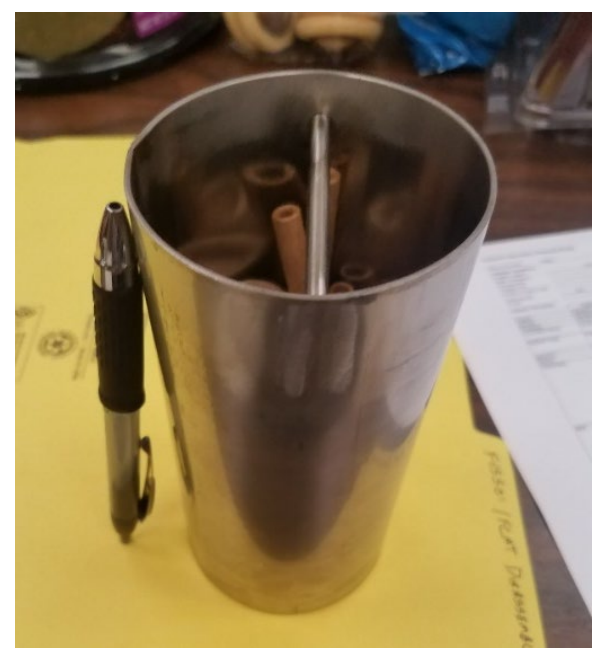

Figure 9. Basket for use in type A drum.

\subsection{Summary}

Table 9 provides a summary of the different characteristics of the type B casks discussed in this section. 
Transportation Planning for Irradiated Fuel-Cladding and Integral FeCrAl Experiments February 2019

Table 9. Summary of the characteristics of the different type B packages

\begin{tabular}{|c|c|c|c|c|c|c|c|c|c|c|c|c|}
\hline & \multirow{2}{*}{$\begin{array}{c}\text { Flexibility; } \\
\text { convenience } \\
\text { of use } \\
(1=\text { poor, } \\
5=\text { good })\end{array}$} & \multirow{2}{*}{$\begin{array}{c}\text { Max. } \\
\text { weight }\end{array}$} & \multirow{2}{*}{ Comments } & \multicolumn{3}{|c|}{ Cavity dimensions } & \multirow{2}{*}{$\begin{array}{c}\begin{array}{c}\text { Pkg. } \\
\text { dimensions } \\
\text { (w/o impact } \\
\text { limiters) }\end{array} \\
\text { OD }\end{array}$} & \multicolumn{2}{|c|}{$\begin{array}{l}\text { Transport } \\
\text { dimensions }\end{array}$} & \multirow{2}{*}{$\begin{array}{l}\text { Max. } \\
\text { content } \\
\text { weight }\end{array}$} & \multirow{2}{*}{$\begin{array}{l}\text { Approx. } \\
\text { shielding }\end{array}$} & \multirow{2}{*}{$\begin{array}{l}\text { Underwater } \\
\text { loading } \\
\text { capability? }\end{array}$} \\
\hline & & & & Height & OD & Height & & Height & Width & & & \\
\hline $\begin{array}{c}\text { Model } \\
\text { 2000 } \\
\text { (GE-2000) }\end{array}$ & $3 *$ & $\begin{array}{l}33,500 \mathrm{lb} \\
15,195 \\
\mathrm{~kg}\end{array}$ & $\begin{array}{l}\text { Feasibility of handling at } \\
\text { IFEL to be determined; } \\
\text { new content to be added to } \\
\text { CoC to allow ATF rods }\end{array}$ & $\begin{array}{c}54 \mathrm{in} \\
1.37 \mathrm{~m}\end{array}$ & $\begin{array}{l}26.5 \mathrm{in} \\
0.67 \mathrm{~m}\end{array}$ & $\begin{array}{l}71 \mathrm{in} \\
1.80 \mathrm{~m}\end{array}$ & $\begin{array}{c}72 \mathrm{in} \\
1.83 \mathrm{~m}\end{array}$ & $\begin{array}{l}131.5 \mathrm{in} \\
3.34 \mathrm{~m}\end{array}$ & $\begin{array}{l}72 \mathrm{in} \\
1.83 \mathrm{~m}\end{array}$ & $\begin{array}{l}5,450 \mathrm{lb} \\
2,472 \mathrm{~kg}\end{array}$ & $\begin{array}{l}4 \mathrm{in} / \\
10.1 \mathrm{~mm} \\
\mathrm{~Pb}\end{array}$ & $\checkmark$ \\
\hline BRR & $2^{*}$ & $\begin{array}{c}32,000 \mathrm{lb} \\
14,515 \\
\mathrm{~kg} \\
\end{array}$ & $\begin{array}{l}\text { Unknown plans for adding } \\
\text { contents, so assume } \\
>2 \text { years if pursued } \\
\end{array}$ & $\begin{array}{l}54 \mathrm{in} \\
1.37 \mathrm{~m}\end{array}$ & $\begin{array}{l}16 \mathrm{in} \\
0.41 \mathrm{~m}\end{array}$ & $\begin{array}{l}77.1 \mathrm{in} \\
1.95 \mathrm{~m}\end{array}$ & $\begin{array}{l}38 \text { in } \\
0.96 \mathrm{~m}\end{array}$ & $\begin{array}{l}119.5 \mathrm{in} \\
3.04 \mathrm{~m}\end{array}$ & $\begin{array}{l}78 \mathrm{in} \\
1.98 \mathrm{~m}\end{array}$ & - & $\begin{array}{c}<8 \text { in } / \\
20.3 \mathrm{~cm} \mathrm{~Pb}\end{array}$ & $\checkmark$ \\
\hline $\begin{array}{l}\text { NAC- } \\
\text { LWT }\end{array}$ & 1 & $\begin{array}{c}52,000 \mathrm{lb} \\
23,587 \\
\mathrm{~kg} \\
\end{array}$ & $\begin{array}{l}\text { Cask loans are expensive } \\
\text { and handling inconvenient }\end{array}$ & $\begin{array}{l}178 \text { in } \\
4.52 \mathrm{~m}\end{array}$ & $\begin{array}{l}13.4 \text { in } \\
0.34 \mathrm{~m}\end{array}$ & $\begin{array}{l}\sim 200 \text { in } \\
5.08 \mathrm{~m}\end{array}$ & $\begin{array}{l}44 \mathrm{in} \\
1.11 \mathrm{~m}\end{array}$ & $\begin{array}{l}232 \text { in } \\
5.89 \mathrm{~m}\end{array}$ & $\begin{array}{l}65.3 \mathrm{in} \\
1.66 \mathrm{~m}\end{array}$ & $\begin{array}{l}4,000 \mathrm{lb} \\
1,814 \mathrm{~kg}\end{array}$ & $\begin{array}{c}5.75 / 14.6 \\
\mathrm{~mm} \mathrm{~Pb}\end{array}$ & $\checkmark$ \\
\hline NRBK-41 & 4 & $\begin{array}{l}9,000 \mathrm{lb} \\
4,082 \mathrm{~kg}\end{array}$ & $\begin{array}{l}\text { Approval to borrow existing } \\
\text { NRBK-41 uncertain; } \\
\text { neither INL nor ORNL is } \\
\text { currently approved } \\
\text { to send loaded shipments }\end{array}$ & $\begin{array}{l}16 \text { in } \\
0.41 \mathrm{~m}\end{array}$ & $\begin{array}{c}5 \text { in } \\
0.13 \mathrm{~m}\end{array}$ & $\begin{array}{c}40 \mathrm{in} \\
1.03 \mathrm{~m}\end{array}$ & $\begin{array}{l}27.2 \text { in } \\
0.69 \mathrm{~m}\end{array}$ & $\begin{array}{l}46.7 \mathrm{in} \\
1.18 \mathrm{~m}\end{array}$ & $\begin{array}{l}48 \mathrm{in} \\
1.21 \mathrm{~m}\end{array}$ & $\begin{array}{l}60 \mathrm{lb} \\
27 \mathrm{~kg}\end{array}$ & $\begin{array}{c}10 \mathrm{in} / \\
25.4 \mathrm{~mm} \mathrm{~Pb}\end{array}$ & $\checkmark$ \\
\hline $10-160 B$ & 1 & $\begin{array}{l}72,000 \mathrm{lb} \\
32,659 \\
\mathrm{~kg}\end{array}$ & $\begin{array}{l}\text { Cask loans are expensive } \\
\text { and handling inconvenient. } \\
\text { Irradiated fuel is not part of } \\
\text { the authorized content }\end{array}$ & $\begin{array}{l}77 \mathrm{in} \\
1.96 \mathrm{~m}\end{array}$ & $\begin{array}{c}68 \mathrm{in} \\
1.73 \mathrm{~m}\end{array}$ & $\begin{array}{c}88 \mathrm{in} \\
2.23 \mathrm{~m}\end{array}$ & $\begin{array}{l}78.5 \mathrm{in} \\
1.99 \mathrm{~m}\end{array}$ & $\begin{array}{l}130 \mathrm{in} \\
3.30 \mathrm{~m}\end{array}$ & $\begin{array}{c}68 \mathrm{in} \\
1.73 \mathrm{~m}\end{array}$ & $\begin{array}{l}14,250 \mathrm{lb} \\
6,464 \mathrm{~kg}\end{array}$ & $\begin{array}{c}1.88 \mathrm{in} \mathrm{/} \\
4.77 \mathrm{~mm} \mathrm{~Pb}\end{array}$ & $\checkmark$ \\
\hline AOS-100A & 4 & $\begin{array}{l}12,500 \mathrm{lb} \\
6,570 \mathrm{~kg}\end{array}$ & \multirow{2}{*}{$\begin{array}{l}\text { Irradiated fissile materials } \\
\text { are not part of the authorized } \\
\text { contents }\end{array}$} & $\begin{array}{c}20 \text { in } \\
0.51 \mathrm{~m}\end{array}$ & $\begin{array}{c}6.5 \text { in } \\
0.17 \mathrm{~m}\end{array}$ & $\begin{array}{c}36 \mathrm{in} \\
0.91 \mathrm{~m}\end{array}$ & $\begin{array}{c}28 \mathrm{in} \\
0.71 \mathrm{~m}\end{array}$ & $\begin{array}{l}75.4 \text { in } \\
1.92 \mathrm{~m}\end{array}$ & $\begin{array}{l}61 \mathrm{in} \\
1.55 \mathrm{~m}\end{array}$ & \multirow{2}{*}{$\begin{array}{l}500 \mathrm{lb} \\
227 \mathrm{~kg}\end{array}$} & $\begin{array}{l}\text { Tungsten (3 } \\
\text { in / } 7.62 \mathrm{~mm} \\
\text { equivalent) }\end{array}$ & $\checkmark$ \\
\hline AOS-050A & 5 & $\begin{array}{c}1,500 \mathrm{lb} \\
680 \mathrm{~kg}\end{array}$ & & $\begin{array}{c}10 \mathrm{in} \\
0.25 \mathrm{~m}\end{array}$ & $\begin{array}{l}3.25 \mathrm{in} \\
0.08 \mathrm{~m}\end{array}$ & $\begin{array}{c}18 \mathrm{in} \\
0.45 \mathrm{~m}\end{array}$ & $\begin{array}{c}14 \mathrm{in} \\
0.35 \mathrm{~m}\end{array}$ & $\begin{array}{l}38.6 \text { in } \\
0.98 \mathrm{~m}\end{array}$ & $\begin{array}{l}35.8 \text { in } \\
0.91 \mathrm{~m}\end{array}$ & & $\begin{array}{l}\text { Tungsten ( } 5 \\
\text { in / } 12.7 \mathrm{~mm} \\
\text { equivalent) }\end{array}$ & $\checkmark$ \\
\hline TN Lab & 5 & $\begin{array}{l}6,173 \mathrm{lb} \\
2,800 \mathrm{~kg}\end{array}$ & $\begin{array}{l}\text { ATF source term to be } \\
\text { compared to the content of } \\
\text { the SAR; licensing } \\
\text { in the US to be initiated }\end{array}$ & $\begin{array}{l}14.2 \text { in } \\
0.36 \mathrm{~m}\end{array}$ & $\begin{array}{l}5.9 \text { in } \\
0.15 \mathrm{~m}\end{array}$ & $\begin{array}{l}43.3 \mathrm{in} \\
1.10 \mathrm{~m}\end{array}$ & $\begin{array}{l}23.6 \mathrm{in} \\
0.60 \mathrm{~m}\end{array}$ & $\begin{array}{l}70.9 \text { in } \\
1.80 \mathrm{~m}\end{array}$ & $\begin{array}{l}43.3 \mathrm{in} \\
1.10 \mathrm{~m}\end{array}$ & - & $\begin{array}{l}\leq 10 \mathrm{in} / \\
25.4 \mathrm{~mm} \\
\text { steel }\end{array}$ & $\begin{array}{l}\text { Not } \\
\text { currently - } \\
\text { amendment } \\
\text { would be } \\
\text { necessary }\end{array}$ \\
\hline
\end{tabular}

* A forklift can be used to bring Model 2000 into the IFEL for handling, while the heavier BRR cask body is more difficult to position.

Both Model 2000 and the BRR can be unloaded outside the hot cell but inside building as long as the contents' dose is not excessive. Model 2000 can probably just clear the penetration into the IFEL hot cell for unrestricted in-cell unloading, while the BRR is too tall to enter the IFEL hot cell. 


\section{ATF-18}

\subsection{Irradiation/Experiment History}

The ATF program at INL was implemented to demonstrate improved fuel and cladding concepts with the potential to replace the Zircaloy- $\mathrm{UO}_{2}$ system currently used in light water reactors (LWRs). The objective of Phase 1 of this program, denoted as the ATF-1 experiment (Figure 10), is to demonstrate fabricability and test hermeticity, fuel/cladding performance, and the structural stability of these concepts by irradiating a test series of capsule experiments in ATR. The most promising fuel and cladding concepts will go through further development during subsequent phases. The ATF-1 experiments were performed in capsules with the cladding and fuel concepts that required investigation. The capsules were used to avoid contact of the cladding with the reactor coolant and to provide a first safety barrier in case of cladding failure. As part of the ATF-1 phase, the ATF-18 capsule containing FeCrAl alloy cladding (C35MN [9]) and $\mathrm{UO}_{2}$ fuel (6 cylindrical pellets) was irradiated in ATR during 6 cycles, from cycle 157C (starting February 10, 2015) through 160A (ending November 8, 2016). ORNL was the design lead for this experiment [10].

The ATF-18 capsule contained 1 rodlet called LOCA FCA-L3 [11]. The characteristics of the capsule are shown in Table 10 [12] [13] [14].

Table 10. Characteristics of the ATF-18 capsule

\begin{tabular}{l|l}
\hline \multicolumn{1}{c|}{ Characteristics } & \multicolumn{1}{c}{ Value } \\
\hline Number of rodlets in the capsule & 1 \\
\hline Rodlet length & $4.529 \mathrm{in} / 115 \mathrm{~mm}$ \\
\hline Rodlet diameter & $0.370 \mathrm{in} / 9.40 \mathrm{~mm}$ \\
\hline Number, type, and locations of pellets in the rodlet & $\begin{array}{l}6 \mathrm{UO}_{2}+2 \mathrm{SiC}, \text { located at the top and bottom of the } \\
\text { fuel pellets stack }\end{array}$ \\
\hline Initial enrichment of the fuel pellet & $4.95 \mathrm{wt} \%{ }^{235} \mathrm{U}$ \\
\hline Total mass of heavy metal before irradiation & $28.824 \mathrm{~g} \mathrm{U}$ \\
\hline Maximum linear heat generation rate & $650 \mathrm{~W} / \mathrm{cm}$ \\
\hline Maximum fissile material equivalent mass & $365 \mathrm{~g}$ \\
\hline Burnup & $10.4 \mathrm{GWd} / \mathrm{MTU}$ \\
\hline
\end{tabular}

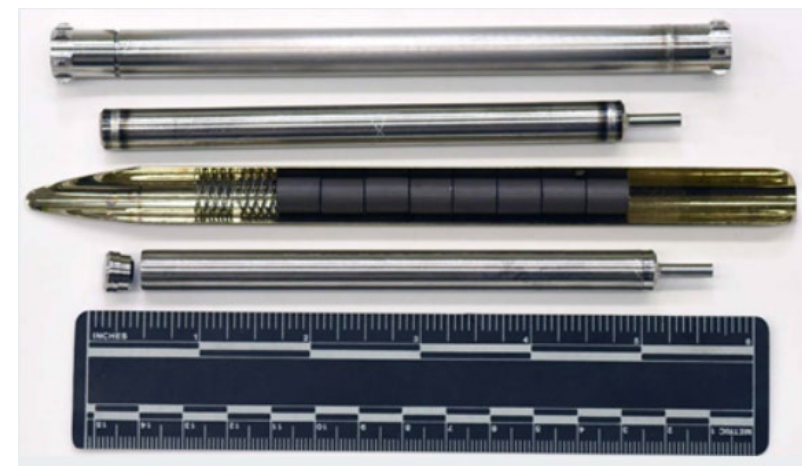

Figure 10. ATF-1 experiment.

The capsule was shipped from ATR to HFEF on February 21, 2017 for PIE [10]. 


\subsection{Current Status}

The rodlet LOCA FCA-L3 has completed its PIE at HFEF. Prior to disassembling the capsule, a fission gas release check on the gas assay, sample, and recharge (GASR) system showed the presence of fission gas in the capsule. In addition, the change in cladding diameter was measured. Finally, neutron radiography of the rodlet showed cracking in the $\mathrm{UO}_{2}$ pellets (see Figure 11 [11]).

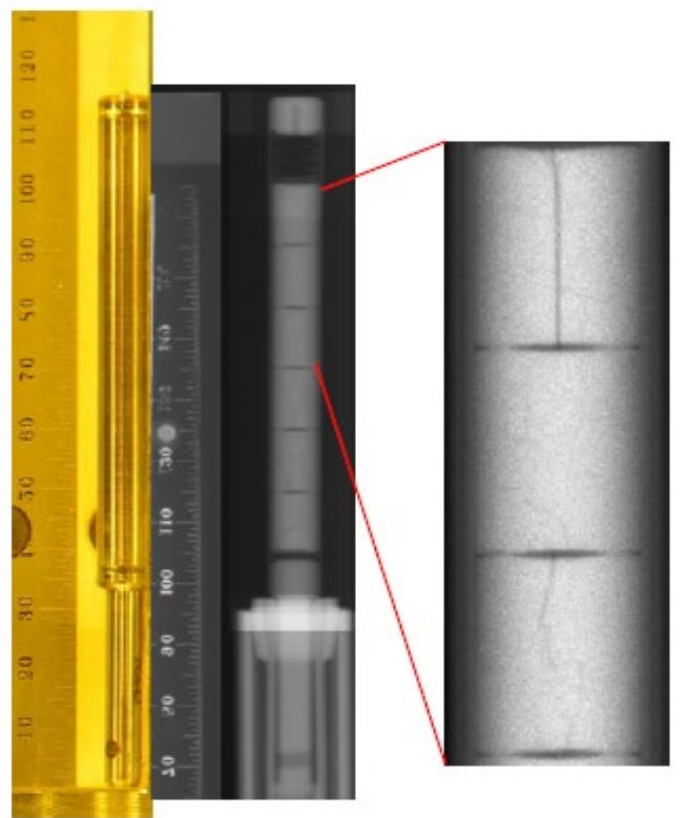

Figure 11. Visual examination and neutron radiography of the ORNL LOCA FCA-L3 rodlet with a neutron radiography detail showing cracking in the $\mathrm{UO}_{2}$ pellets.

This rodlet is currently in storage at INL waiting on shipment to ORNL for use in the Severe Accident Test Station (SATS).

\subsection{PIE Plan}

The goal of the PIE is to assess the effect of irradiation on the chemistry inside the rodlets and on the performance of the cladding material, to include weld integrity and overall geometrical stability [15]. The initial PIE was performed at HFEF [11].

The rodlet is breached and might not be an ideal candidate for integral LOCA testing in the ORNL SATS, but it remains a valuable sample for SATS high temperature oxidation tests, mechanical properties tests, and microstructural characterization of fueled FeCrAl cladding [11].

\subsection{Shipment}

With more than 2 years of cooling time to date, these rodlets would preferably be shipped in a type A package. An analysis of the rodlets' isotopics would be necessary to confirm the feasibility of using a type A package; the source term calculated in the associated engineering calculations [16] will be used for this analysis. Table 11 shows the main radionuclides in terms of activity (radionuclides representing 99.9\% of the total activity from source term calculation [16]). After an initial analysis by ORNL's packaging 
operations team, it has been determined that the rodlet could be shipped in a type A package if it can be assumed that ${ }^{90} \mathrm{Sr}$ and ${ }^{90} \mathrm{Y}$ are in secular equilibrium; otherwise, a type B package would be required.

The 55-gallon type A drum could accommodate the LOCA FCA-L3 rodlet. This experiment is expected to be shipped to ORNL at the end of fiscal year (FY) 2019 to undergo PIE during FY 2020.

Table 11. ATF-18 radionuclides inventory after 2 years of cooling

\begin{tabular}{l|c|c|c}
\hline Radionuclide & Mass (g) & Specific activity (Bq/g) & Activity (Bq) \\
\hline${ }^{144} \mathrm{Ce}$ & $9.70 \mathrm{E}-04$ & $1.182 \mathrm{E}+14$ & $1.15 \mathrm{E}+11$ \\
\hline${ }^{147} \mathrm{Pm}$ & $2.06 \mathrm{E}-03$ & $3.437 \mathrm{E}+13$ & $7.08 \mathrm{E}+10$ \\
\hline${ }^{137} \mathrm{Cs}$ & $1.06 \mathrm{E}-02$ & $3.23 \mathrm{E}+12$ & $3.42 \mathrm{E}+10$ \\
\hline${ }^{90} \mathrm{Y}$ & $1.60 \mathrm{E}-06$ & $2.016 \mathrm{E}+16$ & $3.23 \mathrm{E}+10$ \\
\hline${ }^{90} \mathrm{Sr}$ & $6.36 \mathrm{E}-03$ & $5.057 \mathrm{E}+12$ & $3.22 \mathrm{E}+10$ \\
\hline${ }^{55} \mathrm{Fe}$ & $3.55 \mathrm{E}-04$ & $8.93 \mathrm{E}+13$ & $3.17 \mathrm{E}+10$ \\
\hline${ }^{106} \mathrm{Ru}$ & $1.24 \mathrm{E}-04$ & $1.240 \mathrm{E}+14$ & $1.54 \mathrm{E}+10$ \\
\hline${ }^{85} \mathrm{Kr}$ & $2.55 \mathrm{E}-04$ & $1.455 \mathrm{E}+13$ & $3.71 \mathrm{E}+09$ \\
\hline${ }^{134} \mathrm{Cs}$ & $5.63 \mathrm{E}-05$ & $4.797 \mathrm{E}+13$ & $2.70 \mathrm{E}+09$ \\
\hline${ }^{125} \mathrm{Sb}$ & $4.10 \mathrm{E}-05$ & $3.83 \mathrm{E}+13$ & $1.57 \mathrm{E}+09$ \\
\hline${ }^{95} \mathrm{NB}$ & $8.33 \mathrm{E}-07$ & $1.449 \mathrm{E}+15$ & $1.21 \mathrm{E}+09$ \\
\hline${ }^{241} \mathrm{Pu}$ & $2.59 \mathrm{E}-04$ & $3.819 \mathrm{E}+12$ & $9.89 \mathrm{E}+08$ \\
\hline${ }^{63} \mathrm{Ni}$ & $3.36 \mathrm{E}-04$ & $2.192 \mathrm{E}+12$ & $7.37 \mathrm{E}+08$ \\
\hline${ }^{95} \mathrm{Zr}$ & $6.60 \mathrm{E}-07$ & $7.960 \mathrm{E}+14$ & $5.25 \mathrm{E}+08$ \\
\hline${ }^{155} \mathrm{Eu}$ & $2.81 \mathrm{E}-05$ & $1.72 \mathrm{E}+13$ & $4.84 \mathrm{E}+08$ \\
\hline${ }^{125 m} \mathrm{Te}$ & $5.73 \mathrm{E}-07$ & $6.673 \mathrm{E}+14$ & $3.82 \mathrm{E}+08$ \\
\hline${ }^{91} \mathrm{Y}$ & $2.63 \mathrm{E}-07$ & $9.086 \mathrm{E}+14$ & $2.39 \mathrm{E}+08$ \\
\hline${ }^{154} \mathrm{Eu}$ & $2.03 \mathrm{E}-05$ & $9.78 \mathrm{E}+12$ & $1.99 \mathrm{E}+08$ \\
\hline${ }^{151} \mathrm{Sm}$ & $1.70 \mathrm{E}-04$ & $9.753 \mathrm{E}+11$ & $1.66 \mathrm{E}+08$ \\
\hline${ }^{3} \mathrm{H}$ & $3.91 \mathrm{E}-07$ & $3.578 \mathrm{E}+14$ & $1.40 \mathrm{E}+08$ \\
\hline
\end{tabular}

\section{HALDEN IFA-796}

\subsection{Irradiation/Experiment History}

The testing rig, designated as IFA-796, is composed of 1 full length rod and 5 segmented rods, fueled with $\mathrm{UO}_{2}$ pellets. ORNL supplied FeCrAl cladding material (C06M2) for the full-length rod (Rod 4) and FeCrA1 C06M2 and C36M2 for 2 segments of Rod 3 of this testing rig. The fuel rods from IFA-796 started irradiation in July 2017 and were subjected to 2 short-term irradiations in Halden reactor in Norway, up to a total burnup of $4.9 \mathrm{MWd} / \mathrm{kg} \mathrm{UO} \mathrm{UO}_{2}$ under PWR thermal-hydraulic and water chemistry conditions. The IFA-796.1 rig showed some failure and was discharged from the reactor; the IFA-796.2 rig replaced the previous rig in the reactor [17]. The characteristics of the IFA-796 rig are presented in Table 12 [17] [18] [19]. The end pellets were made from natural $\mathrm{UO}_{2}$ powder with an addition of $3 \mathrm{wt} \% \mathrm{Dy}_{2} \mathrm{O}_{3}$ and $0.5 \mathrm{wt} \% \mathrm{Zn}$-stearate. 
Table 12. Characteristics of IFA-796 experiment

\begin{tabular}{l|l}
\multicolumn{1}{c|}{ Characteristics } & \multicolumn{1}{c}{ Value } \\
\hline Number of rods in the rig & 6 (including a reference rod) \\
\hline Number of segments per rod & 4 (except for Rod 4) \\
\hline Rod length & 23.62 in $/ 60 \mathrm{~cm}$ \\
\hline Segment length & $6.30 \mathrm{in} / 16 \mathrm{~cm}$ \\
\hline Active length stack & $3.94 \mathrm{in} / 10 \mathrm{~cm}$ \\
\hline Number of pellets per segment & 12 fuel pellets +2 end pellets \\
\hline Number of pellets in the full-length rod & 64 fuel pellets +2 end pellets \\
\hline Average pellet density & $95.2 \%$ of theoretical density $\left(10.96 \mathrm{~g} / \mathrm{cm}^{3}\right)$ \\
\hline Initial enrichment of the fuel pellet & $7 \mathrm{wt} \%$ \\
\hline Burnup & $4.9 \mathrm{MWd} / \mathrm{kg} \mathrm{UO}_{2}$ \\
\hline
\end{tabular}

\subsection{Current Status}

Because of the Halden reactor's shutdown, irradiation of IFA-796 was terminated early in June 2018. The experiment is currently at Halden waiting for PIE.

\subsection{PIE Plan}

The goal of the PIE on IFA-796 is to provide information regarding the integral creep and swelling behavior of the cladding, as well as the pellet-cladding mechanical interaction. The PIE measurements are planned to be performed at different facilities and include [18]:

- Visual inspection

- Eddy current / proximity probe measurements

- Profilometry measurements

- Neutron radiography

- Optical metallography

Halden will perform visual inspection and profilometry onsite for all the IFA-796 rods. It has been discussed that the two segments (two different FeCrAl alloys - C36M2 and C06M2) be tested at ORNL (mechanical testing and possibly LOCA test), and that the full-length rod (C06M2 alloy) be tested at Kjeller hot-cell facility in Norway (LOCA test and possibly optical metallography). This would allow to directly compare the behavior of two $\mathrm{FeCrAl}$ alloys tested at the same facility and to obtain some data from two different facilities for the same alloy. In addition, if the length of the material available allows, ORNL will explore ring compression and ring tension.

Considering the low-burnup irradiation of this experiment, it is not expected that the fuel and cladding bond; thus, the segments intended for PIE at ORNL could be de-fueled before being shipped to ORNL.

\subsection{Shipment}

Due to the dimensions of the segments and rods, the 55-gallon type A drum cannot be used for shipping this experiment to ORNL. Considering that only segments will be shipped to ORNL, the TN Lab cask could be a shipping option; it would require that the validation process be initiated to use the cask in the United States. Shipping from Halden only requires the French certificate and a letter of information to the 
competent authority in Norway. An analysis of the isotopics will be necessary to confirm that the experiment is bounded by the current SAR and to confirm the feasibility of the shipment.

Pursuing the license for use of the TN Lab cask is recommended as this cask will not only satisfy the current need but provide the national laboratories with a viable option for small-scale fuel shipments going forward.

\section{HATCH LEAD TEST RODS}

\subsection{Irradiation/Experiment History}

GNF has developed two different types of fuel cladding: IronClad (Figure 12), a C26M FeCrAl alloy cladding developed in collaboration with ORNL; and the Abrasion Resistant More Oxidation Resistant (ARMOR), a coated zirconium fuel cladding. Both claddings are designed to maintain good physical properties under high radiation and in a high-temperature environment and to provide substantial oxidation resistance. ARMOR cladding also provides enhanced protection of fuel rods against debris fretting [20].

GNF has manufactured and delivered an LTA of both claddings to the Southern Nuclear Operating Company for plant installation. The first IronClad and ARMOR LTA were installed in the commercial power reactor Hatch, Unit 1, a BWR located in Georgia, for a start of irradiation in Cycle 29 (February 2018) [15].

The IronClad LTRs are unfueled, segmented fuel-length rods comprised of 6 individual segments [15] plus one extender at each end, while ARMOR LTRs are fueled segmented rods. The LTRs are deployed within standard GNF2 assemblies [21]. The rods were fabricated in 2-foot $(0.61 \mathrm{~m})$ segments that can be removed from the assemblies and shipped. Table 13 shows the segment IDs for each rod, as well as the planned number of irradiation cycles for each LTR. Figure 12 shows a picture of the IronClad LTRs. The C26M IronClad rods are pressurized with gas only and do not contain dummy pellets [22].

Table 13. Characteristics of the IronClad LTRs

\begin{tabular}{|c|c|c|c|}
\hline IronClad LTR & $\begin{array}{lll}\begin{array}{l}\text { Position } \\
\text { (from bottom to top) }\end{array} & \text { segment } \\
\end{array}$ & ID & $\begin{array}{c}\text { Number of irradiation } \\
\text { cycles }\end{array}$ \\
\hline$\# 1$ & $\begin{array}{ll}\text { 1. } & 1 \text { - Lower extender } \\
2 . & 2-\mathrm{C} 26 \mathrm{M} 003 \\
3 . & 3-\mathrm{C} 26 \mathrm{M} 004 \\
4 . & 4-\mathrm{C} 26 \mathrm{M} 005 \\
5 . & 5-\mathrm{C} 26 \mathrm{M} 006 \\
6 . & 6-\mathrm{C} 26 \mathrm{M} 007 \\
7 . & 7-\mathrm{C} 26 \mathrm{M} 008 \\
8 . & 8-\text { Upper extender }\end{array}$ & & 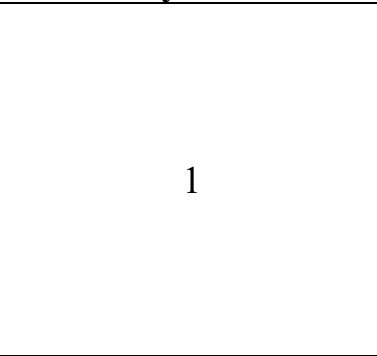 \\
\hline$\# 2$ & $\begin{array}{ll}1 . & 1 \text { - Lower extender } \\
2 . & 2-\mathrm{C} 26 \mathrm{M} 009 \\
3 . & 3-\mathrm{C} 26 \mathrm{M} 010 \\
4 . & 4-\mathrm{C} 26 \mathrm{M} 017 \\
5 . & 5-\mathrm{C} 26 \mathrm{M} 018 \\
6 . & 6-\mathrm{C} 26 \mathrm{M} 019 \\
7 . & 7-\mathrm{C} 26 \mathrm{M} 0020 \\
8 . & 8-\text { Upper extender }\end{array}$ & & 3 \\
\hline
\end{tabular}




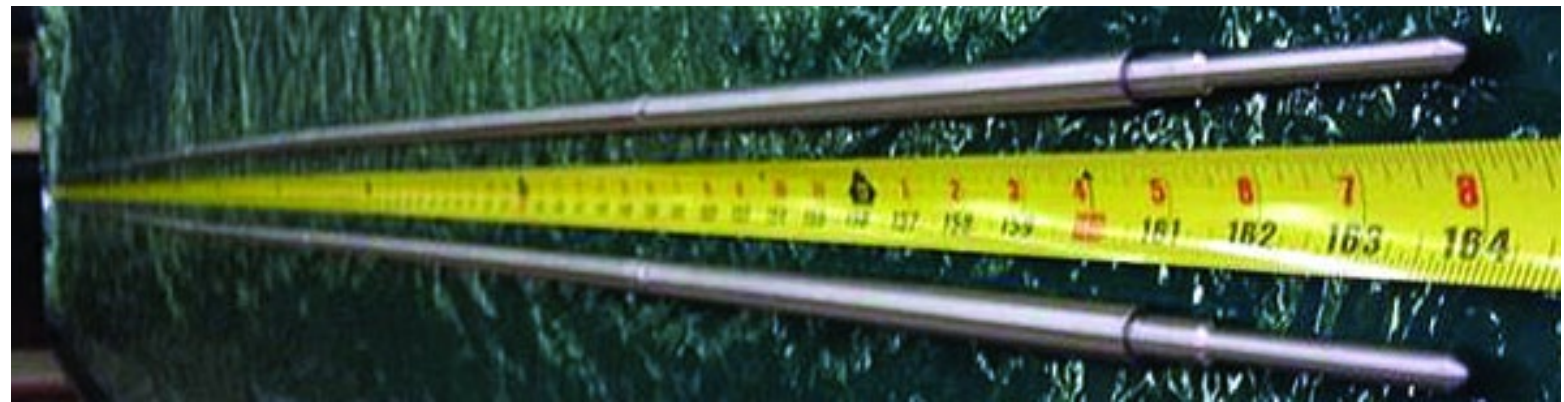

Figure 12. IronClad LTRs [23].

\subsection{Current Status}

Two C26M IronClad LTRs located in two different bundles [22] and four ARMOR LTAs are currently being irradiated in the Edwin I. Hatch Nuclear Plant. One rod of each material will be irradiated for 1 cycle (24 months) ending in February 2020. The second C26M rod will go through two additional cycles.

\subsection{PIE Plan}

The goal of the PIE is to characterize and evaluate the as-irradiated microstructure and measure the mechanical properties of the material [15]. The proposed PIE includes:

- Visual examination to characterize external surface of as-irradiated rod

- Leak tightness test of as-irradiated rod

- Optical and electron microscopy to assess corrosion layer thickness, composition, and metal loss

- Mechanical properties tests to assess strength and ductility characteristics, as well as fracture toughness

- Cyclic loading tests to assess fatigue life

- Biaxial creep testing to assess time-dependent deformation under load

- High temperature oxidation testing to assess response to simulated LOCA conditions

- Annealing tests to assess irradiation damage recovery kinetics

Initial PIE results are expected by January 2021 [15].

\subsection{Shipment}

GNF will provide the resources and capabilities to remove the LTRs from the assemblies. GNF will also be leading all efforts to ship the ATF LTRs for PIE [21].

GNF is considering using the GE-2000 cask for the shipment of IronClad and ARMOR LTRs [15]. The feasibility to receive this cask at IFEL must be studied. In order to ship the IronClad unfueled rods, the rods' source terms and the loading criteria for their shipment under the current GE-2000 CoC must be developed. For ARMOR rods, the GE-2000 SAR (NEDE-33866) must be revised to authorized fueled ATF content. The revision of the SAR will lead to a new NRC-approved CoC (Docket No. 71-9228). Different tasks that will need to be performed for this purpose include: 
- Development of fueled ATF rod source terms

- Shielding evaluations to assure that dose limit requirements are maintained for ATF fueled rods

- Quantification of isotopic thermal loading

- Criticality assessments for special nuclear material and ATF rods

- Licensing and regulatory work for the requested shipping content

The NAC-LWT, known for spent fuel transportation, is another cask option that can be considered for shipment of these experiments. The same tasks listed above for the GE-2000 would be required for shipment of IronClad and ARMOR LTRs using the NAC-LWT.

GE plans to send some segments to ORNL, but the timeline for this shipment is currently uncertain [22]. It is expected that the C26M IronClad segments will be able to be shipped within 30 days after the end of irradiation as a Type A shipment. The ARMOR segments are projected to fall within the shipment's isotopic requirements after about 90 days of cooling time. However, NRC regulations state that spent fuel cannot be shipped with less than one year of cooling, so the necessary cooling time for this experiment will require further evaluation by GNF.

\section{SUMMARY AND CONCLUSIONS}

This report gives an overview of the different candidate casks for shipping ATF experiments. For each of the three ATF experiments, the unresolved shipment information and likely shipment option is summarized below:

- ATF-18: INL to ORNL. The FeCrAl fuel rodlet, currently at INL, is expected to be shipped in a Type A drum; a source term analysis would be necessary to confirm the use of a Type A package.

- IFA-796: Halden to ORNL. The experiment source term and fissile content are required to confirm shipment feasibility using the TN Lab "Flying Pig." The TN Lab cask is under licensing in France and will require a validation of certification for use in the United States.

- Hatch LTR: Edwin I. Hatch Nuclear Plant to ORNL. IronClad and ARMOR rods currently being irradiated in Hatch-1 are expected to be shipped in a GE Model 2000 cask. The source terms for the IronClad and ARMOR rods must be developed. Additional feasibility studies will be performed at ORNL to ensure the GE 2000 can be received at IFEL. Revision of the SAR and the $\mathrm{CoC}$ will be necessary to transport the ARMOR rods, as the current status of the cask does not allow transportation of ATF-fueled rods. Alternatively, the NAC-LWT could be used for shipment of both IronClad (unfueled) and ARMOR (fueled) rods.

The results of the PIE performed on these experiments will provide information of the behavior of ATF concepts under irradiation and will contribute to the overall evaluation of ATF concepts and material property databases.

\section{REFERENCES}

1. Kevin G. Field, Yukinori Yamamoto, Bruce A. Pint, Maxim N. Gussev, and Kurt A. Terrani, "Accident Tolerant FeCrAl Fuel Cladding: Current Status Towards Commercialization," in Proceedings for the 18th International Conference on Environmental Degradation of Materials in Nuclear Power Systems - Water Reactors, 2017. 
2. RAMPAC Radioactive Material Packaging, DOE Packaging Certification Program, Office of Environmental Management.

3. 10 CFR 71, Code of Federal Regulations, title 10 NRC Regulations, Part 71 - Packaging and Transportation of Radioactive Material.

4. 49 CFR 173.7, Code of Federal Regulations, title 19 - Transportation, Section 173.7 - U.S. Government material.

5. International Atomic Energy Agency, "Regulations for Safe Transport of Radioactive Material, SSR-6," IAEA, 2018.

6. GNF presentation, "NRC meeting to Discuss Shipping Accident Tolerant Fuel in the GE Model No. 2000," December 17, 2018.

7. International Atomic Energy Agency, "Regulations for the Safe Transport of Radioactive Material, Specific Safety Requirements No. SSR-6,” IAEA, 2018 Edition.

8. "ADR - European Agreement Concerning the International Carriage of Dangerous Goods by Road," United Nations, 2018.

9. Y. Yamamoto, B. A. Pint, K. A. Terrani, K. G. Field, Y. Yang, and L. L. Snead, "Development and property evaluation of nuclear grade wrought $\mathrm{FeCrAl}$ fuel cladding for light water reactors," J. Nucl. Mater., vol. 467, no. doi:10.1016/J.JNUCMAT.2015.10.019, p. 703-716, 2015.

10. C. J. Murdock, B. J. Curnutt, and C. Hale, "Accident Tolerant Fuels Series 1 (ATF-1) Irradiation Testing FY 2018 Status Report,” INL, September 2018.

11. Jason M. Harp, Fabiola Cappia, and Lica Capriotti, "Postirradiation Examination of the ATF-1 Experiments - 2018 Status,” Idaho National Laboratory, September 2018.

12. Drawing 604496 Rev. 2, Idaho National Laboratory, ATR - ATF (Accident Tolerant Fuel) Experiment ORNL fuel rodlet assemblies, Idaho National Laboratory, March 17, 2014.

13. Drawing 604497 Rev. 1, Idaho National Laboratory, ATR - ATF (Accident Tolerant Fuel) Experiment ORNL Fuel Rodlet end caps and tube detuaks, Idaho National Laboratory, March 17, 2014.

14. ECAR-3305, "ATR Cycles 158B and 159A As-Run Analyses and Cycle 160A Bounding Physics Evaluation of the Accident Tolerant Fuels (ATF) ATF-1-21-2, ATF-1-23-1 and ATF-1-24-5 Basket Configurations," August 2016.

15. GE, “Development of LWR Fuels with Enhanced Accident Tolerance,” 2018.

16. Engineering Calculations and Analysis ECAR No. 3477, "ATF-1 Capsules ATF-13, ATF-15, and ATF-18 End of Irradiation Source Term," January 9, 2017.

17. Email from R. Szoke (IFE) to R. Martin and K. Terrani (ORNL) "RE: IFA-796 irradiated fuels with ATF cladding," August 18, 2018.

18. K. A. Terrani, Y. Yamamoto, and M. Gussev, "Characterization Report on FeCrAl Cladding for Halden Irradiation,” Fuel Cycle Research \& Development Advanced Fuels Campaign, July 2016. 
19. Email from R. Szoke (IFE) to R. Martin and W. Beere (IFE), "RE: IFA-796 irradiated fuels with ATF cladding," January 2, 2019.

20. J. Allen, “GNF Delivers Accident Tolerant Fuel Assemblies for Plant Installation," Wilmington, NC, 2018.

21. Email from J. Chavers (Southern) to A. Le Coq (ORNL), "RE: Hatch-1 ATF PIE planning," December 3, 2018.

22. Email from D. Lutz (GE Power) to R. Fawcett (GE Power), K. Terrani (ORNL) and P. McCumbee (GE Power), “RE: Hatch-1 ATF PIE planning,” November 18, 2018.

23. S. Patel, “Accident-Tolerant Fuels Could be a Boon for Nuclear Industry," Power, April 4, 2018.

24. Drawing SK-NMP-20140815-01 Rev. 0, Oak Ridge National Laboratory, ORNL Lead Shielded 55 Gallon Type-A drum Design. 